\title{
Analisis Kesulitan Belajar Mahasiswa Kategori Nilai Rendah dalam Menyelesaikan Masalah Statistika Pokok Bahasan Ukuran Tendensi Sentral, Ukuran Dispersi, dan Ukuran Letak
}

\author{
Mika Ambarawati \\ Program Studi Bahasa dan Sastra Indonesia IKIP Budi Utomo Malang \\ Jalan Citandui 46 Malang \\ Fitri Apriyani Pratiwi \\ Program Studi Bahasa dan Sastra Indonesia IKIP Budi Utomo Malang \\ Jalan Citandui 46 Malang
}

\begin{abstract}
The aim of this research was to describe the analyzed difficulty learn student category of low value in solving the statistics problems on discussion size measure of central mainstream, size measure dispersi, and the size measure situation. This research used the descriptive research method with the qualitative explorative approach. The subjects of the research were 12 students $2013 \mathrm{~A}$ and 2013 B Program Study of Education Language and literature Indonesia, four students categoryof high value, four students category of medium value, andfour students category of low value. The instruments used to gather data of worksheet for problem solving and interview guidelines. The data were task-based interview on the learning material of statistics problems. They were validated by using the time triangulation and the reference fulfillment. The data were analyzed using a Miles and Huberman's concept, that was data reduction, presentation, and conclusion. The results of the research are as follows. 1) Students categoryof low value not difficulties determining concept, using formula, and calculate solving the statistics problems on discussion size measure of central mainstream. 2) Students categoryof low valuedifficulties determining concept, using formula, and calculate solving the statistics problems on discussion size measure dispersicharacteristic coefficient of variation and permanent deviasi. 3) Students categoryof low valuedifficulties determining concept, using formula, and calculate solving the statistics problems on discussion size measure situationcharacteristic kuartilconcept from data pertain.
\end{abstract}

Keywords: analyzed difficulty learn, problem solving statistics, size measure of central mainstream, size measure dispersi, and the size measure situation

Belajar adalah keseluruhan proses yang melibatkan aktivitas fisik-psikis untuk mendapatkan perubahan positif dalam semua aspek tingkah laku melalui sentuhan dengan lingkungan dan pengalaman (Ula, 2003). Adapun belajar adalah proses aktif yang mana proses pemberian makna dibangun dan dikembangkan berdasarkan pengalamanpengalaman (Suprihatiningrum, 2013). Selain itu, menurut Slameto (2003) belajar adalah suatu proses usaha yang dilakukan seseorang untuk memperoleh suatu perubahan tingkah laku yang baru secara keseluruhan sebagai hasil 
pengamalan sendiri dalam interaksi dengan lingkungan.

Kesulitan belajar merupakan sebagai suatu kondisi dimana anak didik tidak dapat belajar secara wajar, disebabkan adanya ancaman, hambatan ataupun ganguan dalam belajar (Djamarah, 2002).Kesulitan atau kendala belajar yang dialami mahasiswa disebabkan oleh faktor internal dan eksternal.faktor internal adalah faktor yang berasal dari dalam diri mahasiswa, misalnya kesehatan, bakat minat, motivasi, intelelegensi, dan sebagainya. Adapun faktor eksternal adalah faktor yang berasal dari luar mahasiswa, misalnya dari lingkungan rumah, lingkungan sekitar kampus, dan lingkungan masyarakat (Jamal, 2014).

Pembelajaran statistika umumnya berkaitan dengan konsep, rumus, dan cara penghitungan. Kesulitan penguasaan konsep berkaitan dengan penafsiran dan cara menggunakan konsep statistika. kesulitan penguasaan dengan penafsiran dan cara menggunakan rumus-rumus. Kesulitan cara penghitungan berkaitan ketelitian saat melakukan operasi dengan rumus yang telah ditentukan.

Ada beberapa jenis kesalahan yang dilakukan saat menyelesaikan masalah, yaitu (1) kesalahan konsep adalah kesalahan dalam menafsirkan dan menggunakan konsep matematika, (2) kesalahan prinsip adalah kesalahan siswa dalam menafsirkan dan menggunakan rumus-rumus matematika, (3) kesalahan operasi adalah kesalahan siswa dalam menggunakan operasi dalam matematika, dan (4) kesalahan karena kecerobohan adalah kesalahan karena salah dalam perhitungan (Wiyartimi, 2010).

Masalah dalam pembelajaran matematika biasanya diinterpretasikan dalam soal matematika. Suatu soal matematika disebut masalah bagi seorang siswa, jika: (1) pertanyaan yang dihadapkan dapat dimengerti oleh siswa, namun pertanyaan itu harus merupakan tantangan baginya untuk menjawabnya, dan (2) pertanyaan tersebut tidak dapat dijawab dengan prosedur rutin yang telah diketahui siswa (Hudojo, 2005).

Masalah statistika dalam penelitian ini merupakan pertanyaan statistika yang cara pemecahannya tidak dapat ditemukan secara langsung, sehingga pemecahannya harus menyelidiki, membuat kaitan, dan melibatkan pengetahuan yang dimiliki untuk mendapatkan pemecahannya. Adapun dalam penelitian ini masalah statistika berupa soal statistika bersifat terbuka yang membutuhkan kemampuan melihat pola atau membuat dugaan untuk dapat memecahkannya.Soal yang digunakan terbatas pada materi bahasan ukuran tendensi sentral, ukuran dispersi,dan ukuran letak.

Pemecahan masalah dalam penelitian ini adalah mahasiswa dapat menemukan konsep yang akan digunakan untuk menemukan rumus, mengaplikasikan rumus, dan dapat menyelesaikan persoalan yang berkaitan dengan materi ukuran tendensi sentral, ukuran dispersi dan ukuran letak dengan menghitung secara teliti.

Ukuran tendensi sentral merupakan ukuran yang mewakili kumpulan data tertentu dengan suatu ukuran yang mewakilinya, baik untuk populasi maupun untuk sampel.Dinamakan ukuran tendensi sentral, karena ukuran itu cenderung berada di tengahtengah (setelah data diurutkan).Selain ukuran tendensi terdapat pula ukuran dispersi atau ukuran penyebaran.Ukuran ini dapat memberikan gambaran mengenai sebaran dari sekumpulan data. Oleh sebab itu, ukuran ini sering disebut ukuran variasi, seperti jangkauan, simpangan baku, dan variansi. Ukuran letak dari sekolompok data dipakai untuk mengetahui letak suatu nilai setelah suatu kelompok data diurutkan.Ukuran letak yang dibahas adalah kuartil (Budiyono, 2009).

Berdasarkan latar belakang, terdapat pertanyaan penelitian sebagai berikut: 
1. Bagaimana kesulitan mahasiswa kategori rendah dalam penguasaan konsep, menggunakan rumus, dan tehnik perhitungan masalah statistika pokok bahasan ukuran tendesi sentral?

2. Bagaimana kesulitan mahasiswa kategori rendah dalam penguasaan konsep, menggunakan rumus, dan tehnik perhitungan masalah ukuran dispersi?

3. Bagaimana kesulitan mahasiswa kategori rendah dalam penguasaan konsep, menggunakan rumus, dan tehnik perhitungan masalah statistika pokok bahasan ukuran ukuran letak?

\section{METODE}

Jenis penelitian ini adalah penelitian deskriptif dengan pendekatan kualitatifeksploratif. Subjek dari penelitian ini terdiri dari 12 mahasiswa 2013 A dan 2013 B Program Studi Bahasa dan Sastra Indonesia, 4 mahasiswa dengan kategori nilai tinggi, 4 mahasiswa dengan kategori nilai sedang, dan 4 mahasiswa dengan kategori nilai rendah. Instrumen yang digunakan adalah tes pemecahan masalah statistika pokok bahasan ukuran tendensi setral, ukuran dispersi, dan ukuran letak.Instrumen yang digunakan unuk memperoleh data adalah lembar tugas pemecahan masalah dan wawancara berbasis tugas.Teknik keabsahan data yang digunakan pada penelitian ini adalah triangulasi waktu dan menggunakan kecukupan referensi.Data yang dianalisis adalah hasil tes pemecahan masalah statistika dan hasis wawancara untuk mendeskripsikan analisis kesulitan mahasiswa dalam pemecahan masalah tersebut. Sumber data pada penelitian ini adalah siswa sebagai subjek penelitian. Teknik analisis data yang digunakan adalah konsep Miles dan Huberman, yaitu reduksi data, penyajian data, dan penarikan kesimpulan.

Analisis penelitian yang dilakukan adalah analisis kesulitan mahasiswa dalam memahami konsep, menggunakan rumus, dan tehnik perhitungan materi statistika.Adapun indikator dalam analisis kesulitan mahasiswa kesulitan mahasiswa dalam memahami konsep, menggunakan rumus, dan tehnik perhitungan materi statistika sebagai berikut

Tabel 1 Indikator dan Karakteristik Pemecahan Masalah

\begin{tabular}{|c|c|}
\hline Indikator & Karakteristik \\
\hline \multirow{3}{*}{$\begin{array}{l}\text { 1. Kesulitan mahasiswa pada penguasaan } \\
\text { konsep dalam memahami ukuran tendensi } \\
\text { sentral pada populasi dan sampel. }\end{array}$} & $\begin{array}{l}\text { 1.1 Mahasiswa mampu menguasai konsep } \\
\text { rerata hitung }\end{array}$ \\
\hline & $\begin{array}{l}12 \text { Mahasiswa mampu menguasai konsep } \\
\text { rerata dari distribusi frekuensi data tunggal } \\
13 \text { Mahasiswa mampu menguasai konsep } \\
\text { rerata dari distribusi frekuensi data } \\
\text { bergolong }\end{array}$ \\
\hline & $\begin{array}{l}1.4 \text { Mahasiswa mampu menguasai konsep } \\
\text { rerata geometrik dan rerata harmonik } \\
15 \text { Mahasiswa mampu menguasai konsep } \\
\text { mean, median, dan modus pada data } \\
\text { tunggal dan bergolong }\end{array}$ \\
\hline
\end{tabular}




\begin{tabular}{|c|c|}
\hline $\begin{array}{l}\text { 2. Kesulitan mahasiswa pada penggunaan } \\
\text { rumus dalam memahami ukuran tendensi } \\
\text { sentral pada populasi dan sampel. }\end{array}$ & \begin{tabular}{|lll} 
2.1 & Mahasiswa dapat menentukan rumus \\
& rerata hitung yang akan digunakan \\
2.2 & Mahasiswa dapat menentukan rumus \\
rerata dari distribusi frekuensi data tunggal \\
2.3 & Mahasiswa dapat menentukan rumus \\
& distribusi frekuensi data bergolong \\
2.4 & Mahasiswa dapat menentukan rumus \\
geometrik dan rerata harmonik \\
2.5 \\
Mahasiswa dapat menentukan rumus \\
konsep mean, median, dan modus pada \\
data tunggal dan bergolong
\end{tabular} \\
\hline $\begin{array}{l}\text { 3. Kesalahan perhitungan dalam } \\
\text { menyelesaikan permasalahan ukuran } \\
\text { tendensi sentral pada populasi dan sampel. }\end{array}$ & 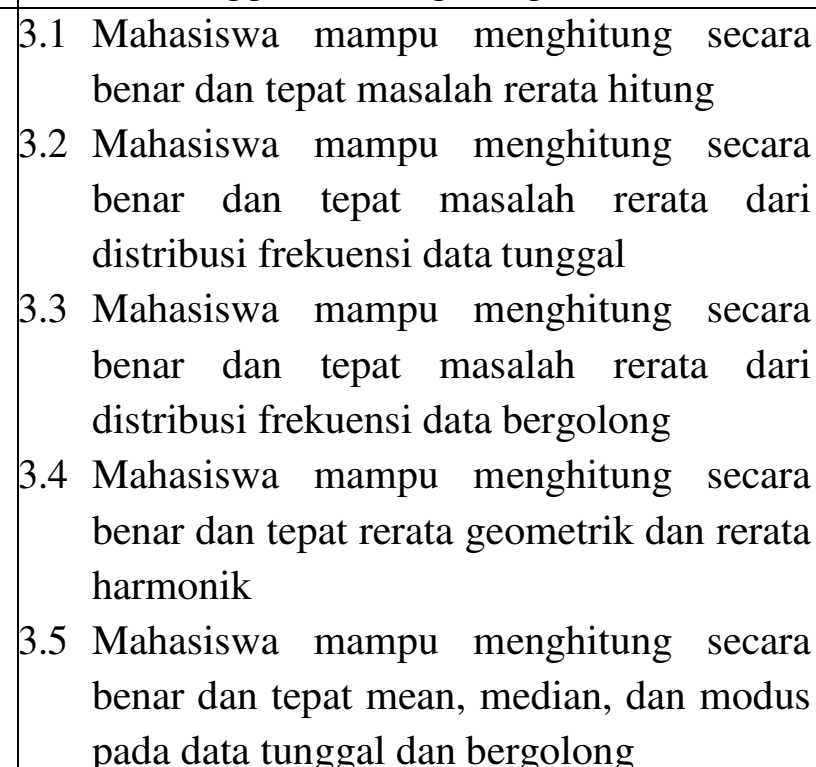 \\
\hline $\begin{array}{l}\text { 4. Kesulitan mahasiswa pada penguasaan } \\
\text { konsep dalam memahami ukuran dispersi } \\
\text { pada populasi dan sampel. }\end{array}$ & $\begin{array}{ll}4.1 & \begin{array}{l}\text { Mahasiswa mampu menguasai konsep } \\
\text { jangkauan }\end{array} \\
4.2 & \begin{array}{l}\text { Mahasiswa mampu menguasai konsep } \\
\text { rerata deviasi }\end{array} \\
4.3 & \begin{array}{l}\text { Mahasiswa mampu menguasai konsep } \\
\text { variansi pada distribusi frekuensi data }\end{array} \\
& \text { tunggal dan bergolong } \\
4.4 & \text { Mahasiswa mampu menguasai konsep } \\
\text { deviasi baku } & \\
45 & \text { Mahasiswa mampu menguasai konsep } \\
\text { koefisien variasi }\end{array}$ \\
\hline $\begin{array}{l}\text { 5. Kesulitan mahasiswa pada penggunaan } \\
\text { rumus dalam memahami ukuran dispersi } \\
\text { pada populasi dan sampel. }\end{array}$ & $\begin{array}{rlrl}\text { 5.1 } & \text { Mahasiswa dapat menentukan rumus } \\
& \text { jangkauan } & & \\
5.2 & \text { Mahasiswa dapat menentukan rumus } \\
& \text { konsep } \\
& \text { rerata deviasi } \\
5.3 & \text { Mahasiswa dapat menentukan rumus } \\
& \text { variansi pada distribusi frekuensi data } \\
& \text { tunggal dan bergolong } \\
5.4 & \text { Mahasiswa dapat menentukan rumus }\end{array}$ \\
\hline
\end{tabular}




\begin{tabular}{|c|c|c|}
\hline & 5.5 & $\begin{array}{l}\text { deviasi baku } \\
\text { Mahasiswa dapat menentukan rumus } \\
\text { koefisien variasi }\end{array}$ \\
\hline $\begin{array}{lcr}\text { 6. Kesalahan } & \text { perhitungan } & \text { dalam } \\
\text { menyelesaikan } & \text { permasalahan } & \text { ukuran } \\
\text { dispersi pada populasi dan sampel. } & \end{array}$ & {$\left[\begin{array}{l}6.1 \\
6.2 \\
6.3 \\
6.4 \\
6.5\end{array}\right.$} & $\begin{array}{l}\text { Mahasiswa mampu menghitung secara } \\
\text { benar dan tepat masalah jangkauan } \\
\text { Mahasiswa mampu menghitung secara } \\
\text { benar dan tepat rerata deviasi } \\
\text { Mahasiswa mampu menghitung secara } \\
\text { benar dan tepat variansi pada distribusi } \\
\text { frekuensi data tunggal dan bergolong } \\
\text { Mahasiswa mampu menghitung secara } \\
\text { benar dan tepat deviasi baku } \\
\text { Mahasiswa mampu menghitung secara } \\
\text { benar dan tepat koefisien variasi }\end{array}$ \\
\hline $\begin{array}{l}\text { 7. Kesulitan mahasiswa pada penguasaan } \\
\text { konsep dalam memahami ukuran letak. }\end{array}$ & 7.1 & $\begin{array}{l}\text { Mahasiswa mampu menguasai konsep } \\
\text { kuartil data tunggal } \\
\text { Mahasiswa mampu menguasai konsep } \\
\text { kuartil dari distribusi data bergolong }\end{array}$ \\
\hline $\begin{array}{l}\text { 8. Kesulitan mahasiswa pada penggunaan } \\
\text { rumus dalam memahami ukuran letak. }\end{array}$ & 8.1 & $\begin{array}{l}\text { Mahasiswa dapat menentukan rumus } \\
\text { kuartil data tunggal } \\
\text { Mahasiswa dapat menentukan rumus } \\
\text { kuartil dari distribusi data bergolong }\end{array}$ \\
\hline $\begin{array}{l}\text { 9. Kesalahan perhitungan dalam } \\
\text { menyelesaikan permasalahan ukuran letak. }\end{array}$ & 9.1 & $\begin{array}{l}\text { Mahasiswa mampu menghitung secara } \\
\text { benar dan tepat kuartil data tunggal } \\
\text { Mahasiswa mampu menghitung secara } \\
\text { benar dan tepat kuartil dari distribusi data } \\
\text { bergolong }\end{array}$ \\
\hline
\end{tabular}

Miles dan Huberman mengemukan bahwa aktivitas dalam analisis data kualitatif dilakukan secara interaktif dan berlangsung secara terus menerus sampai tuntas, sehingga datanya sudah jenuh. Aktivitas analisis data, yaitu data reduction, data display, dan conclusion drawing / verification (Sugiyono, 200).

\section{HASIL}

Hasil analisis kemampuan subjek dalam memecahkan masalah dan hasil wawancara sebagai berikut. a. Mahasiswa kategori nilai rendah tidak mengalami kesulitan dalam penguasaan konsep permasalahan ukuran tendensi sentral pada populasi dan sampel adalah

1) Mahasiswa menguasai konsep rerata hitung dengan jelas

2) Mahasiswa menguasai konsep rerata dari dari distribusi frekuensi data tunggal dengan jelas

3) Mahasiswa menguasai konsep rerata dari frekuensi data bergolong dengan jelas

4) Mahasiswa menguasai konsep rerata geometrik dan rerata harmonik dengan jelas 
5) Mahasiswa menguasai konsep mean, median, dan modus pada data tunggal dan bergolong dengan jelas

b. Mahasiswa kategori nilai rendah tidak mengalami kesulitan dalam menentukan rumus permasalahan ukuran tendensi sentral pada populasi dan sampel adalah

1) Mahasiswa dapat menentukan rumus rerata hitung yang akan digunakan dengan mudah

2) Mahasiswa dapat menentukan rumus rerata dari distribusi frekuensi data tunggal dengan mudah

3) Mahasiswa dapat menentukan rumus distribusi frekuensi data bergolong dengan mudah

4) Mahasiswa dapat menentukan rumus geometrik dan rerata harmonik dengan mudah

5) Mahasiswa dapat menentukan rumus konsep mean, median, dan modus pada data tunggal dan bergolong

c. Mahasiswa tidak mengalami kesulitan dalam menghitung permasalahan yang berkaitan ukuran tendensi sentral pada populasi dan sampel adalah

1) Mahasiswa menghitung secara benar dan tepat masalah rerata hitung

2) Mahasiswa menghitung secara benar dan tepat masalah rerata dari distribusi frekuensi data tunggal

3) Mahasiswa menghitung secara benar dan tepat masalah rerata dari distribusi frekuensi data bergolong

4) Mahasiswa menghitung secara benar dan tepat rerata geometrik dan rerata harmonik

5) Mahasiswa menghitung secara benar dan tepat mean, median, dan modus pada data tunggal dan bergolong

d. Mahasiswa tidak mengalami kesulitan dan ada yang mengalami kesulitan dalam menguasai konsep permasalahan ukuran dispersi pada populasi dan sampel adalah
1) Mahasiswa mampu menguasai konsep jangkauan dengan jelas

2) Mahasiswa mampu menguasai konsep rerata deviasi dengan jelas

3) Mahasiswa mampu menguasai konsep variansi pada distribusi frekuensi data tunggal dan bergolong dengan jelas

4) Mahasiswa tidak menguasai konsep deviasi baku dengan jelas

5) Mahasiswa tidak mampu menguasai konsep koefisien variansi dengan jelas

e. Mahasiswa tidak mengalami kesulitan dan ada yang mengalami kesulitan dalam menentukan rumus permasalahan ukuran dispersi pada populasi dan sampel.

1) Mahasiswa dapat menentukan rumus jangkauan dengan mudah

2) Mahasiswa dapat menentukan rumus konsep rerata deviasi dengan mudah

3) Mahasiswa dapat menentukan rumus variansi pada distribusi frekuensi data tunggal dan bergolong dengan mudah

4) Mahasiswa tidak dapat menentukan rumus deviasi baku dengan mudah

5) Mahasiswa tidak dapat menentukan rumus koefisien variasi dengan mudah

f. Mahasiswa tidak mengalami kesulitan dan ada yang mengalami kesulitan dalam menghitung permasalahan yang berkaitan ukuran dispersi pada populasi dan sampel.

1) Mahasiswa menghitung secara benar dan tepat masalah jangkauan

2) Mahasiswa menghitung secara benar dan tepat rerata deviasi

3) Mahasiswa menghitung secara benar dan tepat variansi pada distribusi frekuensi data tunggal dan bergolong

4) Mahasiswa tidak menghitung secara benar dan tepat deviasi baku

5) Mahasiswa tidak dapat menghitung secara benar dan tepat koefisien variasi

g. Mahasiswa tidak mengalami kesulitan dan ada yang mengalami kesulitan dalam penguasaan konsep permasalahan ukuran letak adalah 
1) Mahasiswa mampu menguasai konsep kuartil data tunggal dengan jelas

2) Mahasiswa tidak mampu menguasai konsep kuartil dari distribusi data bergolong dengan jelas

h. Mahasiswa tidak mengalami kesulitan dan ada yang mengalami kesulitan dalam menentukan rumus permasalahan ukuran letak adalah

1) Mahasiswa dapat menentukan rumus kuartil data tunggal dengan mudah

2) Mahasiswa tidak dapat menentukan rumus kuartil dari distribusi data bergolong dengan mudah

i. Mahasiswa tidak kesulitan dalam menghitung dan ada yang mengalami kesulitan permasalahan yang berkaitan dengan ukuran letak adalah

1) Mahasiswa menghitung secara benar dan tepat kuartil data tunggal

2) Mahasiswa tidak menghitung secara benar dan tepat kuartil dari distribusi data bergolong

\section{PEMBAHASAN}

Berdasarkan analisis di atas, maka dapat dibahas hasil penelitian sebagai berikut. Mahasiswa dengan kategori nilai rendah tidak mengalami kesulitan dalam menguasai konsep ukuran tendensi sentral. Namun, mengalami kesulitan dalam menguasai konsep ukuran disperse pada karakteristik konsep koefisien variasi dan karakteristik konsep deviasi baku. Selain itu, mengalami kesulitan ukuran letak pada karakteristik konsep kuartil dari data bergolong.

Mahasiswa dengan kategori nilai rendah tidak mengalami kesulitan dalam menemukan rumus ukuran tendensi sentral. Namun, mengalami kesulitan dalam menguasai konsep ukuran disperse pada karakteristik rumus koefisien variasi dan karakteristik rumus deviasi baku. Selain itu, mengalami kesulitan ukuran letak pada karakteristik konsep kuartil dari data bergolong.

Mahasiswa dengan kategori nilai rendah tidak mengalami kesulitan dalam menghitung rumus pada permasalahan ukuran tendensi sentral. Namun, mengalami kesulitan menghitung rumus pada permasalahan ukuran disperse pada karakteristik konsep koefisien variasi dan karakteristik deviasi baku. Selain itu, mengalami kesulitan ukuran letak pada karakteristik konsep kuartil dari data bergolong.

Hasil penelitian ini didukung penelitian terdahulu yang dilakukan oleh Ungky Pawestri, dkk (2013).Penelitian terdahulu menggunakan siswa kelas $\mathrm{X}$ Imersi SMA Negeri Karangpandan Karanganyar.Berdasarkan hasil penelitian diperoleh bahwa mahasiswa mengalami kesulitan konsep dalam beberapa karakteristik.Ternyata hasil penelitian Ungky Pawestri, dkk juga berlaku pada penelitian ini, meskipun dilakukan dengan subjek, kategori, dan materi yang berbeda.Selain itu, didukung dari hasil wawancara terlihat bahwa mahasiswa mengalami kesulitan konsep dalam beberapa karakteristik.

Selain itu, hasil penelitian ini didukung penelitian terdahulu oleh Fakhrul Jamal (2014).Penelitian terdahulu menggunakan siswa kelas XI IPA SMA Muhammadiyah Meulaboh.Berdasarkan hasil penelitian diperoleh bahwa mahasiswa mengalami kesulitan menggunakan rumus dalam beberapa karakteristik.Ternyata hasil penelitian Fakhrul Jamal juga berlaku pada penelitian ini, meskipun dilakukan dengan subjek, kategori, dan materi yang berbeda.Selain itu, didukung dari hasil wawancara terlihat bahwa mahasiswa mengalami mengalami kesulitan menggunakan rumus dalam beberapa karakteristik.

Berdasarkan hasil penelitian diperoleh bahwa mahasiswa mengalami kesulitan proses menghitung dalam beberapa karakteristik. 
Ternyata hasil penelitian Ungky Pawestri, dkk juga berlaku pada penelitian ini, meskipun dilakukan dengan subjek, kategori, dan materi yang berbeda.Selain itu, didukung dari hasil wawancara terlihat bahwa mahasiswa mengalami kesulitan menghitung dalam beberapa karakteristik.

\section{KESIMPULAN DAN SARAN}

Berdasarkan analisis data dari penelitian yang dilakukan, dapat disimpulkan sebagai berikut. (1) Mahasiswa dengan kategori rendah tidak mengalami kesulitan dalam mentukan konsep, menggunakan rumus, dan menghitung permasalahan ukuran tendensi sentral. (2) Mahasiswa dengan kategori rendah mengalami kesulitan dalam mentukan konsep, menggunakan rumus, dan menghitung permasalahan ukuran dispersi pada karakteristik koefisien variasi dan deviasi baku. (3) Mahasiswa dengan kategori rendah mengalami kesulitan dalam mentukan konsep, menggunakan rumus, dan menghitung permasalahan ukuran letak pada karakteristik kuartil dari data bergolong.

Adapun saran dari hasil penelitian ini adalah untuk dosen pengampu mata kuliah statistika diharapkan memberikan diktat/bahan ajar/modul pada mahasiswa untuk mempermudah proses perkuliahan. Selain itu, dosen dapat memberikan solusi akan kesulitan yang dihadapi mahasiswa dalam menyelesaikan masalah statistika saat menguasai konsep, menentukan rumus, dan menghitung dengan rumus tertentu.

\section{DAFTAR RUJUKAN}

Budiyono. 2009. Statistika Untuk Penelitian. Surakarta: Sebelas Maret University Press.

Fakhrul Jamal.2014. Analisis Kesulitan Belajar Siswa dalam Mata Pelajaran Matematika Pada Materi Peluang Kelas XI IPA SMA Muhammadiyah Meulaboh Johan Pahlawan.Jurnal Pendidikan Matematika. 1 (1): 18-36.

Herman Hudojo. 2005. Pengembangan Kurikulum dan Pembelajaran Matematika. Malang: Universitas Negeri Malang.

Jamil Suprihatiningrum. 2013. Strategi Pembelajaran. Yogyakarta: Ar-Ruzz Media.

Ungky Pawestri, dkk. 2013. Analisis Kesulitan

Pembelajaran Matematika dengan

Pengantar Bahasa Inggris Pada Materi

Pokok Bentuk LOgaritma Kelas X

Imersi SMA Negeri Karangpandan Karanganyar 2012/2013.Jurnal

Pendidikan Matematika. 1 (1).1-7.

Slameto. 2003. Belajar dan Faktor-faktor Yang Mempengaruhinya. Jakarta: Bumi Aksara.

Sugiyono. 2008. Memahami Penelitian

Kualitatif. Bandung : Alfabeta.

S. Shoimatul Ula. 2013. Revolusi Belajar.

Yogyakarta: Ar- Ruzz Media.

Syaiful Bahri Djamarah. 2002. Psikologi Belajar. Jakarta: Rineka Cipta.

Wiyartimi, dkk. 2010. Diagnosa Kesulitan

Belajar Matematika Siswa Pada Materi Trigonometri Rumus-rumus Segitiga Di Kelas X SMA Negeri 50 Jakarta. Jurnal Matematika, Aplikasi,dan Pembelajaran. 9 (2): 89-99. 